\title{
El mundo mágico en el Madrid de los Austrias a través de las cartas, avisos y relaciones de sucesos
}

BEATRIZ VITAR

\section{INTRODUCCIÓN}

La España del siglo XVII, como es ya conocido, presentaba un cuadro conflictivo: monarcas débiles y validos todopoderosos, guerras en múltiples frentes, fuerte descenso demográfico y crisis financieras, por sólo mencionar algunas de las facetas de un panorama desalentador, en el que sin embargo brillaba el genio de artistas como Velázquez y de escritores como Cervantes, Lope de Vega o Quevedo. En esa época, en la que España experimentó una de sus crisis más profundas, se enmarca todo un conjunto de expresiones, muy diversas y curiosas, de lo que Caro Baroja (1973: 35) definiera como el "sentido mágico de la existencia".

A través de las noticias seleccionadas para el tratamiento de los aspectos supersticiosos en el Madrid de los Austrias, un variopinto conjunto de prodigios y de personajes dedicados a los oficios esotéricos irrumpen en la cotidianeidad de una Villa y Corte que parecía vivir bajo el encantamiento. Para el análisis de las particularidades de este fenómeno, es importante tener en cuenta el contexto cultural de la época, el Barroco, que impregna "las más variadas manifestaciones de la vida social y de la obra humana" (Maravall 1975: 42) ${ }^{1}$. En este sentido, no deben perderse de vista las contradicciones de la cosmovisión barroca y las formas supersticiosas presentes en la religiosidad de aquel tiempo, como así también la vigencia de la monarquía absoluta y de la férrea moral contrarreformista, todo ello en el marco de fuertes crisis económicas y sociales; lo que significa, en suma, atender a las circunstancias en las que se desenvuelven las so-

\footnotetext{
1 «No se puede abstraer el Barroco como un periodo del arte, ni siquiera de historia de las ideas. Afecta y pertenece al ámbito total de la historia social, y todo estudio de la materia, aunque se especifique muy legítimamente en los límites de uno u otro sector, ha de desenvolverse proyectándose en toda la esfera de la cultura" (Maravall 1975: 48).
} 
ciedades "sometidas a la creencia en el poder de magos, brujos y hechiceros" (Caro Baroja 1973: 12). A su vez, el estudio del pensamiento mágico en el siglo Xvi nos obliga a alejarnos de nuestro propio criterio acerca de lo que conforma las fronteras de la realidad (ibid:: 10), para situarnos en la mentalidad del Barroco y sus expresiones extrarracionales. Por lo demás, aunque no compete a los alcances de este trabajo ahondar en las disquisiciones referidas a las relaciones entre Magia y Religión ${ }^{2}$, cabría recordar la teoría de Malinowski (1974) acerca del recurso a la brujería en las sociedades con síntomas de frustración y desesperanza (citado por Caro Baroja 1973: 111), lo cual resultaría perfectamente aplicable al contexto español en el siglo de los Austrias.

El desarrollo del ocultismo en la España del siglo XVII se presenta como un hecho generalizado, que atraviesa a la sociedad en su conjunto. Empezando por la cúpula del poder, encontramos que el propio ámbito palaciego obraba como un centro difusor de noticias mágicas: reyes embrujados, prodigios que anunciaban la suerte o desdicha de la monarquía, marqueses endemoniados y damas hechiceras llevadas a la Inquisición, entre otras ${ }^{3}$. Además el Santo Oficio, avocado a perseguir las herejías y "Otras desviaciones del pensamiento" (Gómez Centurión 1999: 277), contaminado a su vez de tales creencias, disponía de un minucioso entramado legal para el castigo de las mismas, al igual que en las diversas congregaciones religiosas se contaba con una abundante literatura de producción propia, para alertar a los fieles respecto de las acechanzas de demonios y brujas.

Por lo demás, no resulta extraño que en un tiempo en el que muchas campos del conocimiento apenas se habían explorado, se adjudicase un carácter sobrenatural a fenómenos o sucesos para los que se carecía de respuestas. Esto se pone de relieve sobre todo en el terreno de lo psicológico, pues una variada gama de comportamientos humanos sólo alcanzaba a medirse bajo el rasero común de la locura o de la posesión

\footnotetext{
${ }^{2}$ Frazer (1944) establece la diferencia entre ambas según las formas en que el hombre se conduce en relación a lo sobrenatural. Así, las manifestaciones religiosas pondrían el acento en la súplica, mientras que las supersticiosas estarían determinadas por la manipulación. A este respecto, Cone y Pertti (1979: 109) sostienen que sería más útil aimaginar un continuo que en un extremo presenta prácticas mágicas, pragmáticas, orientadas al individuo, y en el otro oraciones y ritos públicos».

${ }^{3}$ Ya lo decía un cronista de la Villa quien, a pesar de sus múltiples noticias sobre el mundo fantástico de Madrid, creía que las versiones sobre fantasmas en el Retiro eran "mentira y patarata, que de estar en la Corte se dicen muchas cada día" (Avisos de don Jerónimo de Barrionuevo [29-V-1658] 1968, II: 186-187). En adelante, las referencias a esta fuente se harán de forma abreviada dentro del texto.
} 
diabólica; sabido es que el demonio fue el recurso que se tenía más a mano para valorar todo aquello que resultase desconocido o temible y también para impartir lecciones moralizantes a la cristiandad.

Finalmente, a pesar de que la complejidad y la riqueza del tema le hacen merecedor de una exhaustiva investigación, por razones de espacio nos limitaremos aquí a presentar sólo algunas reflexiones acerca de las circunstancias en las que se desarrollaron y de las motivaciones que subyacían en las diversas manifestaciones de lo mágico en el Madrid barroco.

\section{La Villa y Corte De Madrid en el SIGlo XVII}

La condición de Villa y Corte que ostentaba Madrid desde 1565 había supuesto una afluencia importante de personas procedentes de diferentes puntos del territorio peninsular; componían estos contingentes quienes venían a ocupar un puesto dentro de la burocracia palaciega o, sobre todo, a la búsqueda de un medio de vida en la ciudad, en una época caracterizada por el éxodo rural y la concentración urbana de la población (Maravall 1975). La presencia, entre otros buscavidas, de esa legión de "capigorras" (embusteros que se hacían pasar por adivinos o astrólogos) que señalara Liñán y Verdugo (1620), no es ajena a este flujo humano hacia Madrid. Además, el tema podría ejemplificarse, en términos económicos - valga la comparación-, por medio de la ley de la oferta y la demanda: tal proliferación de embusteros en la Villa y Corte, a pesar de las restricciones legales, se debía a que sus servicios se "cotizaban".

El Madrid de los Austrias, especialmente durante el reinado de Felipe IV, fue escenario casi permanente de celebraciones de todo tipo, en una demostración perfecta de ese gusto barroco por el brillo y las fiestas (Maravall 1975: 484-493). Las festividades religiosas, las coronaciones de reyes, los agasajos a invitados extranjeros y las representaciones teatrales (entre los acontecimientos públicos más destacados), tenían lugar en medio de un gran boato, de luminarias y de fuegos de artificio ${ }^{4}$, elementos todos que componían una escenografía magnética e idónea para demostrar la magnificencia de la monarquía ante los ojos de sus súbditos. En tal entorno no era de extrañar, pues, que las clases menos pudientes, meras espectadoras del lujo y del poder de los grandes, aspirasen a formar parte de ese círculo áulico que se regodeaba entre el oro, la pedrería y el ter-

${ }^{4}$ Véase, al respecto, la descripción del eje imaginario de esa "ciudad mágica" en la etapa en que Madrid era "capital barroca e imperial", en Ringrose (1995: 199-240). 
ciopelo, viniendo muy a cuento el comentario de un ensayista del siglo XVII acerca de lo que aparentaba ser una urepública de hombres encantados, viviendo fuera del orden natural de las cosas" (González Cellórigo [1600], en Díez Borque 1977: 16).

Por lo demás, la misma configuración edilicia de Madrid, producto, por un lado, de su condición cortesana y, por otro, de la proliferación de conventos e iglesias que llegaron a ocupar un tercio del área urbana, hacían de aquélla una "típica ciudad conventual, de ambiente opresivo y misterioso, lleno de seducción" (Chueca Goitia 1991: 15). Este abigarrado conjunto poblacional habría constituido el marco adecuado para albergar, entre sus vericuetos, los canales por donde circulaban las turbias aguas de lo esotérico, lo que junto con los múltiples espectáculos, fiestas y romerías que se celebraban en el siglo XvII, convenientemente fomentados desde el poder (Maravall 1975), obraría como una válvula de escape a la opresión ejercida por los poderosos y a las calamidades de todo tipo que caracterizaron a dicha centuria.

\section{LAS FUENTES: CARTAS, AVISOS Y RELACIONES}

Al escoger para nuestro análisis un tipo particular de testimonios del siglo XVII, representado por las cartas (que a veces eran de "avison), los avisos (que podían darse o no a través de cartas) y las relaciones (que, a su vez, tenían su origen en avisos o cartas), debemos remitir necesariamente a una serie de estudios que analizan cada uno de estos géneros (Étienvre 1996; Infantes 1996), marcando sus diferencias, su intencionalidad informativa y el público al que iban dirigidos, destacándose en cualquiera de los casos la función de informar junto con la de avisar o advertir con fines prácticos, morales o políticos (Étienvre 1996; Tierno Galván 1965). Mas, aparte de esta caracterización (y de la confluencias entre los diversos géneros entre sí $^{5}$ ) o del carácter manuscrito o impreso (especialmente en el caso de las relaciones) conviene sobre todo, acorde con los objetivos de nuestro análisis, tener presente que la información relacionada con la brujería y con la hechicería, "es mucho más abundante del lado del que cree en brujas que del lado del que se cree a si mismo brujo o

\footnotetext{
5 Infantes (1996: 211) define la relación como un aimpreso breve e informativo de carácter no periódicon, rasgo este último que por el contrario sí reúnen los avisos (Étienvre 1996). A su vez los avisos (dirigidos a personas relevantes que permanecen en el anonimato), suelen insertar la información de las relaciones, como puede verse en las Cartas de Almansa y Mendoza (1886) y en los Avisos de Barrionuevo (1968).
} 
bruja" ${ }^{6}$ (Caro Baroja 1973: 10-11), observación que podría hacerse extensiva a muchas de las cuestiones "mágicas" aquí tratadas.

Los avisos constituyen un precedente del periodismo que como tal alcanza plena forma en el siglo xviII; este género gacetillero que más tarde despertaría la crítica de los enciclopedistas - Voltaire lo calificaba de "narración de bagatelas" (citado por Albert 1990: 24)—, en cierta medida se prestaba a la divulgación de "disparates" de usual consumo en una Corte obsesionada por los embrujos. No lejos de la verdad se hallaba Voltaire, ya que el mismo cronista Ayala Manrique, en uno de sus avisos del año 1638 decía, en relación a las hazañas de unos marqueses tahures, que referiría "un cuento muy gracioso, pues que en las Gacetas va de cuento" ${ }^{7}$. Pero ésta es sólo una de las facetas de los noticiarios ${ }^{8}$ de la época, los que junto con las cartas y relaciones - referidas estas últimas a un suceso en particular-, poseen un gran valor testimonial como vehículos de transmisión de la ideología del poder y como instrumentos para el estudio de las mentalidades en el siglo del Barroco.

Los autores de los avisos y de las cartas eran hombres con cierta preparación, que se dedicaban al oficio de informar a personas influyentes de todo lo que sucedía en la Corte y más allá de sus fronteras. Además de brindar abundantes noticias sobre temas políticos, económicos o bélicos, las cartas con avisos o simplemente los avisos contienen abundantes referencias a las cuestiones mágicas. Ciertas expresiones vertidas por algún cronista nos hacen pensar que los asuntos esotéricos ayudaban quizás a matizar la seriedad o gravedad de otros sucesos, contribuyendo a mantener constante el flujo informativo; en sus cartas, el cronista Barrionuevo aparece preocupado por hacer llegar a su destinatario (un deán de Zaragoza) todo tipo de nuevas, en especial si éstas traspasaban la normalidad: "Cualquier papel curioso que llegue a mis manos o de gracejo, le tendrá vuestra merced luego allá, para que con esto y dos amigos a la chimenea pase el tiempo" (Barrionuevo [17-XII-1657] 1968, II: 127). Los gacetilleros del siglo XVII eran, por lo demás, individuos con amplias relaciones en la Corte; de otro modo no se explica la difusión de tantas noticias relativas a las vicisitudes de las guerras sostenidas en diversos fren-

\footnotetext{
${ }^{6}$ En cursiva, en el original.

7 Biblioteca Nacional de Madrid (en adelante BNM), Manuscrito (en adelante Mss) n. ${ }^{\circ} 18.447$, f. $126 \mathrm{v}$.

${ }^{8}$ No ahondaremos aquí en la ordenación o clasificación de las noticias, en su variedad, en el intervalo entre las mismas y en otras cuestiones formales referidas a estos géneros informativos, por entrar propiamente en la esfera de la génesis y desarrollo del periodismo.
} 
tes, a las mil y una intrigas cortesanas, a las "faltas" de las reinas y a sus preñeces o a los viajes de los monarcas a El Escorial o al Retiro.

Las cartas y las relaciones incorporaban, según se ha visto, avisos de diferente procedencia, aunque un volumen importante lo constituían los asuntos cortesanos. Barrionuevo (muy vinculado con el ambiente palaciego por lazos de parentesco ${ }^{9}$ ), hacía alusión, en una de sus cartas, a las novedades recogidas en sus habituales visitas a palacio, una auténtica "mina" para su quehacer periodístico:

Como me van dando las nuevas todos los días que voy a Palacio, en llegando a casa lo escribo luego, con que vengo a comprender tantas cosas distintas y de tierras tan apartadas que, a no ser de este modo, qué cabeza bastara para decir tanto (Barrionuevo [3-X-1654] 1968, I: 63).

Esta comunicación directa con las fuentes de información garantizaba la transmisión de noticias de primera mano pero también la difusión de rumores, que de por sí acababan "generando" un acontecimiento ${ }^{10}$. En el caso del citado Barrionuevo, no se sabe a ciencia cierta la identidad de su proveedor de noticias, aunque sí nos consta su posición y grado de influencia y también cómo el cronista buscaba congraciarse con él, para no perder su pasto cotidiano; no otro fin perseguía la demanda hecha a su destinatario de unos mazos de naipes de Orihuela, para un grande amigo, muy noticioso, de quien me valgo para los avisos, fuera de que es gran letrado y valido en esta Corte" (Barrionuevo [30-XII-1654] 1968, I: 100).

Las inclemencias del tiempo o las irregularidades de los correos creaban a veces vacíos informativos ${ }^{11}$, que los cronistas buscarían remediar apelando a su febril imaginación, como pueden atestiguarlo ciertas noticias fundadas en rumores - palaciegos o callejeros- o en un deficiente conocimiento o manipulación de los hechos ${ }^{12}$. De ahí también la preocu-

\footnotetext{
${ }^{9}$ Este cronista era, según sus propias referencias, primo de Alonso de Peralta y Cárdenas, embajador de España en Londres (Barrionuevo [25-XI-1654], 1968, I: 83).

${ }^{10}$ Estos matices se reflejan en uno de los avisos de Barrionuevo, donde le comunica a su destinatario que "le dará noticias de cuanto pasare, que tengo unos encañados valientes por donde sé el agua que viene a la fuente, si es turbia o corre con claridad" (ibid.).

${ }^{11}$ En una de sus misivas, Barrionuevo le advertía a su destinatario: "Señor mío: Démonos un hartazgo de nuevas, pues hay ocasión para hacerlo, que el invierno lo pagaremos todo junto, no teniendo ocasión de esparcirnos en tiempo tan encogido" (ibid. [7-X-1654], I: 65).

${ }_{12}$ Pellicer se negaba, sin embargo, a abultar sus avisos con noticias que corrían asin substancia o fundamento" ([Aviso de 3-I-1640] 1790, Semanario Erudito, XXXI: 117). En adelante, las referencias a este autor se harán de forma abreviada dentro del texto.
} 
pación por estampar, después de la narración del suceso prodigioso o poco creíble, la frase: "Es cosa cierta", o "Dios sobre todo", en el caso de reproducir horóscopos, prohibidos por la Iglesia en tanto práctica que atentaba contra el libre albedrío.

Pero no sólo de "palacio" vivían los cronistas del xvi sino también de aquellos corrillos de la Villa - los mentideros- y, en suma, de lo que ofrecía el propio ámbito callejero, donde circulaba información de todo tipo. Así, muchas de las noticias insertadas en las crónicas tenían su origen en las hojas de ciego (las relaciones impresas), de cuya veracidad dudaba un cronista como José de Pellicer, según se lee en uno de sus Avisos: "Los ciegos venden esa patarata que remito sobre ciertos prodigios que se han visto en Constantinopla, y sueños del Turco ${ }^{13}$ ya puede ser tenga alguna experiencia de verdad" (Pellicer [28-VI-1639] 1790: 146).

Las relaciones, por otra parte, presentan un rico contenido de cara al análisis del pensamiento del Barroco y del espíritu contrarreformista de la época, como lo demuestran algunos estudios realizados sobre este tipo de documentación. En contraste con los avisos, no iban dirigidas a un individuo en particular sino al lector anónimo, con el objetivo de ejemplarizar, advertir o moralizar; además, el propósito de llegar al gran público se cumplía exitosamente mediante la difusión de las relaciones en forma impresa ${ }^{14}$, corriendo su venta callejera por cuenta de los ciegos (Infantes 1996: 212-216).

En suma, con respecto a las fuentes utilizadas para la elaboración de estas notas, la presencia en las crónicas de personajes pertenecientes a las capas sociales más altas, aquejados por los efectos de acciones mágicas y el relato de prodigios poco creíbles contenidos en las relaciones, nos coloca ante la necesidad de detenernos en el examen "de la conciencia del que se juzga víctima de los brujos y brujas" (Caro Baroja 1973: 11). En este sentido, los cronistas, como elementos representativos de un estrato social de cierta consideración, pero al fin y al cabo agentes informativos que tomaban el pulso cotidiano a una ciudad en la que convivían personas de la más diversa condición social y origen étnico (no deben

${ }^{13}$ Se alude aquí a una relación de 1639 en la que se informa de cosas prodigiosas y de las visiones y sueños pavorosos que tuvo el Gran Turco, como anuncio de la caída de su Imperio bajo las armas de los cristianos (véanse al respecto los comentarios de Redondo 1996: 291-293).

${ }^{14}$ La edición de algunas relaciones manuscritas indica el interés por una mayor divulgación del suceso que anunciaban (Infantes 1996: 208). En este aspecto, la proliferación de impresos con fines de adoctrinamiento se vio favorecida por el desarrollo de la imprenta; bien lo subrayaba un cronista: “felicísima está España en nuestra edad, en lo que es materia de libros" (Liñán y Verdugo 1620: 94). 
olvidarse los sectores minoritarios y marginales, representados por los moriscos, los gitanos y los judaizantes), al hablar de demonios, hechicerías y otras supersticiones, testimonian acerca de la mentalidad de una época y ponen de relieve el papel ejercido por los grupos de poder para inspirar el temor a Dios y mantener la sujeción de los súbditos. Atento a estas consideraciones, puede afirmarse que desde la misma Corte se propiciaba una atmósfera mágica a fin de disfrazar la realidad mísera en que vivía el pueblo y, en general, las calamidades a que estuvo expuesto el siglo ${ }^{15}$. La presentación de ciertos hechos como "sobrenaturales" sin duda aliviaría al poder de toda responsabilidad en relación a las estrecheces y penurias que afectaban a los sectores menos favorecidos.

\section{EL MADRID MÁGICO}

En la Corte de los Austrias, sugestionada por la melancólica existencia de reyes y príncipes "hechizados", eran moneda corriente los agüeros o los presagios, los alquimistas y los astrólogos, los curanderos y las brujas, y un largo etcétera de personas y de sucesos dotados de un carácter mágico. No deja de resultar paradójico, como señalara Blázquez Miguel (1989), que mientras desde la cúpula del poder se alimentaban un sinfín de supersticiones, un Tribunal que representaba el fanatismo religioso y la pureza de la fe persiguiera todas estas prácticas "embusteras", reservando a sus autores una variada gama de castigos que podían ir desde los azotes y el desfile con coroza, hasta el destierro o la hoguera.

\section{Los alquimistas}

En unos tiempos signados por las dificultades financieras de la monarquía (que debía sustentar, entre otras cosas, numerosas guerras y una nobleza parasitaria), no es de extrañar que hasta la Corte misma llegasen los alquimistas. Las críticas circunstancias económicas de la época ${ }^{16}$ pro-

15 Maravall (1975: 45) destaca, a este respecto, los medios desplegados por la Iglesia, la monarquía y los grupos privilegiados a fin de "vigorizar estos aspectos extrarracionales y servirse de ellos".

${ }^{16}$ A este propósito, cabe recordar el notorio endeudamiento de la monarquía española a raíz de sus empresas imperiales y también la ufuga en masan de metales preciosos frente a un volumen considerable de importaciones en la Península (Vilar 1981: 70-71). 
piciaron las andanzas de estos personajes o más bien el cúmulo de noticias en torno a sus supuestas hazañas: aún se esperaba encontrar la piedra filosofal, comentaba Ayala Manrique, "porque se oye a todos los que afirman que saben hacer oro y plata" ${ }^{17}$. Muchas de las aventuras alquimistas no salían a la luz debido a la reserva con que se habrían practicado tan quiméricos ensayos a solicitud de los monarcas, pero lo que no constituía ningún secreto era que también en la alquimia incursionaban los hombres de la Iglesia — presente, de un modo u otro, en la vida mágica de entonces-. Así encontramos a un fraile carmelita calzado quien, tras propagar la especie de que podía obtener plata a partir de cualquier otro metal, acabó protagonizando el bochornoso episodio de "haber hecho diferentes veces sus diligencias" ante una Junta de plateros de la Villa, sin resultados satisfactorios: la "masa" obtenida "no era plata ni nada" ${ }^{18}$. Por no dejar de soñar con quimeras se podía incluso reincidir, prestando de nuevo oídos a personajes tan peregrinos como aquel Vivencio Lupati que a pesar de sus antecedentes - había estado preso por uembustero"-, fue llevado al alcázar de Segovia "adonde lexplicaba el cronista antes citado] dicen que hace plata y la ba becho" ${ }^{19}$ (El subrayado es nuestro). De este rumor sobre el presunto prodigio realizado por el alquimista "aislado" en el castillo segoviano se hacía eco un destacado arbitrista de la época, advirtiendo sobre la inconveniencia de la empresa ante la posibilidad de que los enemigos de España la imitasen y por el desperdicio que supondría el no explotar las riquezas metálicas de América: “Dado que alguno supiese hacer plata [sentenciaba el arbitrista], no convendría al servicio de S.M. que la hiciese, porque los holandeses la harian también y las Indias no nos serían de provecho" ${ }^{20}$.

Aunque el episodio arriba citado indicaría cierta tolerancia para con los alquimistas, éstos llegaron también a ser procesados por la Inquisición, tal como le ocurrió a Pedro Milanés, que además de astrólogo y alquimista era un "buscador contumaz de tesoros" y diestro en proporcionar "ayudas" para la consecución de fines amorosos (Villarín 1989: 32-33). Por su parte, los zahoríes o buscadores de tesoros, de metales preciosos o de aguas subterráneas, eran en su mayoría de origen morisco, oficio y condición que les valió el estigma de hechiceros (Blázquez Miguel 1989: 185). No es de extrañar que la Inquisición persiguiera a tales personajes, que se proclamaban conocedores de las capas acuíferas del subsuelo y

\footnotetext{
17 BNM (Mss 18.447, f. 103).

${ }^{18}$ Ibid.

19 Ibid., f. 31v.

${ }^{20}$ Ibid., fs. 103 y $103 \mathrm{v}$.
} 
del método aplicado por los árabes para extraer las aguas subterráneas mediante una compleja red de canales; sistema éste que, cabe decir, había alcanzado especial desarrollo en Madrid, alzada "mágicamente" sobre el agua (Oliver Asín 1959).

\section{Los tesoros encantados}

Dentro del anecdotario mágico del siglo XVII madrileño se encuentran las noticias sobre la existencia de fabulosos tesoros escondidos por los árabes, rumores muchas veces alentados por el hallazgo de restos arqueológicos importantes (Blázquez Miguel 1989: 180). Las crisis económicas que atravesó España en aquella centuria - y en especial la notoria fuga de metales preciosos destinados al pago de las deudas imperiales- podrían haber alimentado fábulas de este tipo, tal como puede apreciarse en una carta de Barrionuevo, donde se comentaba que al labrador que anunció el descubrimiento de un tesoro, le habían mandado "diese cuenta a la justicia para que se remediase España" (Barrionuevo [19-VII-1656] 1968, I: 299). Estas fantasías, que a veces tenían su origen en los sueños habidos por el supuesto descubridor, contaban entre sus protagonistas, por lo general, a moriscos, frailes ${ }^{21} \mathrm{y}$, claro está, a los emisarios reales que se personaban de inmediato en el lugar en cuestión ${ }^{22}$. En lo relativo al encantamiento de los tesoros, éste era un rasgo "previsible,, en tanto que la posibilidad de obtener riquezas fabulosas brindaba la ocasión de aleccionar acerca del pecado de la codicia, recurriéndose de inmediato a los "fantasmas o encantos", en suma a la "ilusión diabólica", para disuadir a hipotéticos buscadores y monopolizar las autoridades la exploración del supuesto tesoro ${ }^{23}$. Todos estos elementos están presentes en los "prodigios" que se empezaron a anunciar en relación al tesoro que se decía haber encontrado en un poblado de Huete, en Cuenca, provincia que, dado su "esplendoroso y fascinante pasado medieval", es señalada como una de las localidades castellanas "más proclive a estas creencias" (Blázquez

${ }^{21}$ En el caso, valga de ejemplo, del tesoro "hallado" en Astorga (suceso que el cronista describe con un estilo digno de Las mil y una noches), el morisco había convencido al fraile de que le haría rico si "le ayudaba" a desenterrarlo (Barrionuevo [29V-1656] 1968, I: 282).

${ }^{22}$ Al día siguiente de llegar a palacio la noticia de uno de los tesoros de Huete (Cuenca), se presentaron alli "el Consejo Real y sala de gobierno" (ibid. [19-VII-1656], I: 299).

${ }^{23}$ Barrionuevo informa también de que el Rey aha librado ya dos mil ducados en Huete para los que van trabajando" (ibid. [30-VIII-1656], I: 305). 
Miguel 1989: 183). En aquellas "cuevas muy hondas", el mozo que se había animado a explorarlas se había topado con salones suntuosos, hermosas ninfas y enormes cantidades de oro y de plata, a las que sin embargo ni siquiera había podido arrimar la mano, pues "se le opuso delante una sierpe redonda como araña, grande como la rueda de un carro, que con las uñas y garras se lo estorbón" (Barrionuevo [30-VIII-1656], 1968, I: 305), clara alusión ésta al demonio, que adoptaba a veces la forma de un reptil ${ }^{24}$; a escasa distancia de este tesoro se decía haber encontrado otro, aunque una vez más el buscador sería objeto de la burla de Satán. Finalmente, todo acabó denunciándose en la Inquisición, aunque al parecer ésta no hacía demasiado caso al tema de los tesoros encantados (Blázquez Miguel 1989: 181) ${ }^{25}$.

La única certeza que puede rescatarse de tales "hallazgos" es que jamás se logró acceder a los tesoros que se suponían enterrados en tales cuevas, salvo quizá a una que otra pieza que podría haberse recogido, al tratarse posiblemente de algún yacimiento arqueológico. Las evidentes contradicciones que ofrece el relato de Barrionuevo sobre esta cuestión así lo sugieren, pues tras anunciar el hallazgo de monedas de plata y de cobre y de algunas piedras preciosas, al cabo de una semana se vuelve al principio, informándose del desarrollo de las operaciones de "asalto" al fabuloso depósito a través de un espacio laberíntico poblado de obstáculos, pareciendo, expresa la noticia, que "tantas prevenciones, soterrados, aposentos, puertas y llaves esconden, sin duda alguna, cosa grande" (Barrionuevo [27VII-1656] 1968, I: 320). Pero el suspense y la aventura acaban ahí, al menos en los avisos del citado cronista, sin que hayamos visto, por fin, franquearse la celosa puerta de acceso a las riquezas anunciadas.

\section{Astrología y pronósticos}

Dentro de los arquetipos humanos que nutrían la crónica mágica de Madrid, los astrólogos ocupaban un lugar importante ${ }^{26}$, dado su carácter de "profesionales" al servicio del poder. En contra de la prohibición rei-

${ }^{24}$ La víbora representa además, en asociación con la pérdida del paraíso original, la suprema tentación diabólica.

${ }^{25}$ Con relación a este suceso se iniciaron al parecer varios procesos inquisitoriales, aunque Barrionuevo se mostraba escéptico sobre su resultado: «Plegue a Dios no paren todos en humo como los de este género suelen ser" (Barrionuevo [30-VIII-1656] 1968, I: 305$)$.

${ }^{26}$ La Astrología había obtenido el rango de asignatura dentro de los planes de estudio de la Universidad de Valencia, en los siglos XVI y xVII (Blázquez Miguel 1989: 199). 
nante que desautorizaba cualquier forma de predicción del futuro, los astrólogos pululaban en la Villa y Corte, contando, entre su clientela, a los propios reyes ${ }^{27} \mathrm{y}$ a la aristocracia. Sabido es que casi todas las monarquías europeas acogían a hombres de ciencia que estudiaban los astros y predecían el porvenir, y la española no habría de ser una excepción, dado el contexto mágico en que se desenvolvía la vida de la época y, en particular, la de palacio. Contra esta afición por los horóscopos se alzaban algunas voces críticas, entre ellas la de Pellicer, que hacía gala de un no disimulado desdén hacia los estudiosos de los astros al escribir la necrológica del padre Andrés de León, “de los Clérigos menores", que había sido "grande Matemático y Astrólogo, y por esta habilidad tan inútil, muy consultado en la Corte de todos los que creen en los delirios de la Astrología (Pellicer [11-III-1642] 1790: 225). No obstante la opinión adversa de ciertos sectores, los astrólogos - y también los aprendices de tales- tenían de antemano justificado su oficio, al ser quienes interpretaban los presagios que se hallaban in situ en los portentos observados en el firmamento o en diversos acontecimientos "prodigiosos" (nacimientos de seres anormales, aparición de monstruos, catástrofes naturales, etc.), para luego confeccionar los pronósticos; predicciones éstas que, en muchos casos, revestían el carácter de profecías o de mensajes con fines moralizantes.

No obstante, de cara a los horóscopos, fueron principalmente los fenómenos celestes los más propicios para que los astrólogos echasen a rodar sus predicciones, hecho que nos sitúa ante una de las manifestaciones más sobresalientes de la cultura y del pensamiento del Barroco: el contraste entre lo racional (expresado en el logro de avances científicos que permitían observar, como en este caso, los movimientos astrales con precisión), y los comportamientos extrarracionales (que adjudicaban a tales acontecimientos la condición de "anunciadores" de fortunas o de desgracias). A pesar de que los cronistas se hacían eco de lo anunciado en los pronósticos, se cuidaban de demostrar una obediencia ciega a éstos, anteponiendo mediante frases como "Dios sobre todo" - habitualmente usada por Barrionuevo, por ejemplo - la "racionalidad" dictada por la confianza en la Providencia.

Entre quienes se dedicaban a la astrología y a la matemática ${ }^{28}-\mathrm{y}$ también a la elaboración de pronósticos-, se hallaban algunos miembros

${ }^{27}$ Felipe III llegó a solicitar una carta astral al nacer el que luego reinaría con el nombre de Felipe IV (Villarín 1989: 198).

${ }^{28}$ También estos estudiosos escudriñaban los fenómenos celestes, para discernir sus augurios: “Los matemáticos que han alzado figura sobre los cometas de estos días atrás dicen que por todo este año se ha de descubrir lo roso y lo velloso y así es fuerza estar a la mira de lo que sucediere. Todo lo encamine Dios de su santísima mano". Avisos de Madrid por Francisco Bravo [30 de marzo de 1620], en BNM, Mss 18.666(67). 
del clero e integrantes de diversas órdenes religiosas, siendo común en el Barroco esta "convergencia" entre ciencia y religión (Maravall 1975: 145). La Compañía de Jesús, por ejemplo, contaba entre sus filas con un núcleo de "expertos" que estudiaban los fenómenos celestes y en especial los eclipses ${ }^{29}$ que, por lo demás, han despertado una gran inquietud y un cúmulo de predicciones en todo tiempo y lugar ${ }^{30}$. En este afán por desentrañar presagios, se podía llegar incluso a practicar un estudio retrospectivo, analizando los vaticinios que, formulados en el pasado ante iguales fenómenos, pudiesen estar a punto de cumplirse; estas preocupaciones le habían llevado a Barrionuevo ([11-X-1656] 1968, II: 7), seguramente que con ánimo de dar primicias, a consultar el libro de los eclipses de Estéfano Justino, "que dice todo cuanto ahora nos va sucediendo en España" y también los escritos de un contador de la Inquisición en Córdoba, "doctísimo en esta materia". Con respecto a los cometas, la abundancia de predicciones $-\mathrm{y}$ de predicadores- en torno a su aparición estuvo propiciada por la variedad de formas y de tamaños —además del sitio hacia donde "apuntaba" la cola - con los que se podían presentar ${ }^{31}$.

Los pronósticos u horóscopos solían anunciar, por lo general, acontecimientos relacionados con el papado y el Imperio o con la monarquía española y la marcha de sus negocios bélicos. Otro tipo de predicciones -como, por ejemplo, las concernientes a la evolución de las guerras que España sostenía en múltiples frentes-, bien podían ser el equivalente de las opiniones de un comentarista de hoy especializado en tales temas, sustentadas en ciertas dotes para el análisis y en los datos proporcionados por la misma experiencia, del mismo modo que el "progreso" o la "ruina" de una nación podían ser fácilmente predecibles mediante el seguimiento del rumbo de sus asuntos económicos ${ }^{32}$.

\footnotetext{
${ }^{29}$ Precisamente en la Compañía de Jesús se estaba escribiendo, en 1641, sobre el eclipse de sol observado un año atrás en las Indias; dadas las connotaciones fantásticas con que se presentaba el ambiente americano en el imaginario europeo (dotado, a su vez, de su propia "carga mágica"), no ha de sorprendernos este interés jesuítico por estudiar aquel fenómeno, que había acontecido "con aspectos y señales bien terribles y raras" (Pellicer [3-IX-1641] 1790: 124).

${ }^{30}$ Hace poco se ha tenido ocasión de experimentarlo, a raíz del eclipse de sol producido el 11 de agosto de 1999, que en Madrid se vio parcialmente.

${ }^{31}$ Así, en 1618, uuna cometa muy grande" había anunciado la muerte del "santo" Arzobispo de Toledo, Bernardo de Sandoval, la de Felipe III y la de "muchas cabezas de personas particulares y de consideración" (BNM, Mss 2.395, fs. 47 y 69v.).

32 Así se daba a entender en el Mercurio, impreso publicado en Portugal (país de donde procedían, al igual que de Francia, muchos de los pronósticos que circulaban en España), en cuyo número de enero de 1655, el autor del ahoróscopo para ese
} 
Sumado al ambiente supersticioso en que se desenvolvía la vida de Madrid en aquel entonces, circunstancia "normal" en una sociedad "que por todas partes se sentía asaltada de nuevos males" (Maravall 1975: 90), desde las más altas esferas del poder se manipulaba la información en aras de reafirmar la vigencia de las instituciones y de mantener el rígido orden moral y social establecido. Percibidos el papado y la monarquía como instituciones tutelares, objeto de la veneración cuando no de la adulación de sus súbditos, los "anuncios" que se recogían de algunos fenómenos o prodigios generalmente se referían a la desaparición de sus representantes, experimentada en cierto modo como una borfandad ${ }^{33}$. Los pronósticos que hacían alusión a la vida de papas y reyes no hacían sino reforzar el carácter "divino" de éstos, de modo tal que sus muertes no podían acaecer sin más y sí, en cambio, estar precedidas por señales extraordinarias; ello explica que desde la cúpula del poder se intentase controlar la circulación de los pronósticos, poniéndolos al servicio de sus intereses. Conforme a estos supremos dictados, estaban destinados a una mayor difusión los vaticinios - por lo usual basados en catástrofes o hechos alarmantes-, de talante aleccionador para los fieles o los que pronosticaban, por ejemplo, una "gran dicha impensada" para la monarquía de los Austrias (Barrionuevo [9-XII-1654] 1968, I: 91); por el contrario, la censura corría sin tardanza para los horóscopos que sólo predecían desgracias - poniendo de relieve la ineptitud de los monarcas-, como había ocurrido con los del año 1655, que tardarían en llegar a las manos de Barrionuevo: "Dícese que no los dejan imprimir, y que es por grandes infortunios que prometen a nuestra pobre España" (ibid. [26-XII-1654], I: 98) ${ }^{34}$. La preocupación por las vicisitudes del papado estaba presente en

año advertía que "no lo hace por las estrellas, sobre que dominan las disposiciones humanas, sino por los antecedentes de que ordinariamente resultan las consecuencias" (BNM, Mss. 2.392).

33 Tampoco escapaba a los presagios la figura del "Rey de Romanos", cuya muerte había sido anunciada, mucho antes de que ocurriese, por el vuelo inesperado de un águila vieja y enferma que habitaba en palacio, por un cielo tenebroso y por un descomunal diluvio, señales todas de que el Imperio "no ha de durar más en la Casa de Austria" (Barrionuevo [26-VIII-1654], 1968, I: 52).

${ }^{34}$ No cabe duda de que la publicación de noticias adversas a la suerte de las armas trataría de impedirse a toda costa, a fin de no desmoralizar a quienes cargaban con el peso de las guerras. De tales procederes informa Barrionuevo, lamentándose no sólo del poco caso que se había hecho del pronóstico de Cádiz para el año de 1655 - que aconsejaba "cuenta y ojo con Portugal — sino también de su ocultamiento: «ya le han recogido [expresaba a su destinatario], que no quieren oír amenazas, aunque sean de los astros" (ibid. [16-I-1655], I: 103-104). 
muchos pronósticos, como en aquél de 1655 que auguraba al nuevo pontífice una "muy corta vida", y a su sucesor, el logro de "la paz entre los príncipes cristianos" (ibid. [20-III-1655], I: 117), vaticinio que, por otra parte, habla bien a las claras del deseo de unidad de la Europa católica bajo la autoridad del Sumo Pontífice. A su vez, la publicación de los "milagros" papales -aunque, en sentido estricto, los milagros son atributos de la divinidad-, contribuía a reforzar la condición indiscutible de su autoridad y el halo divino de su figura, según se observa en un aviso de Barrionuevo, donde el Pontífice aparece deteniendo con una simple bendición una feroz carga de rayos, demostrando la "virtud y fuerza que tiene el Vicario de Dios en la tierran (ibid. [12-XII-1657], II: 124).

Con respecto a los reyes, tanto sus personas como sus residencias y, en general, todo lo que les rodeaba, aparecen señalados en las cartas y avisos como receptores de presagios a través de determinados fenómenos o prodigios. Llegado el caso, los teólogos podían incluso admitir, mediante dictamen, alguna profecía bajo la que subyace el carácter divino de la monarquía, activándose así uno de los mecanismos de que disponía la Iglesia para ponerse al servicio de aquélla; así lo sugeriría la "legitimada" profecía que anunciaba que unas nubes de extraños colores en el cielo serían la señal de que "saldría del Purgatorio y entraría en la gloria el alma del Católico Rey Don Felipe Segundo" (León Pinelo 1971: 181-182). Pero a veces la propia persona del monarca era "escogida" por la divinidad para hacer sus revelaciones, tal como había sucedido con el rey Felipe III, que había llegado a presagiar su muerte, pareciendo que "quiso Dios darle este conocimiento tan firme para que dispusiese con más prevención su alma para el último trance" (ibid:: 232). Por otra parte, el ámbito de palacio, como albergue del poder supremo del monarca y como eje de gravitación de la vida política de entonces, solía también acusar indicios divinos, aunque a veces los mismos informantes se negaban a aceptarlo como cierto; un aviso de 1641 daba cuenta de un globo de fuego o luz" que atravesó todo Madrid hacia las nueve de la noche:

pasó por Palacio y se deshizo de la otra parte de la Priora, hacia el Parque. Andan varios juicios de Astrólogos: mi sentir es que el aire, que le hacía grande aquel día, le arrastró de región caliente (Pellicer [7-V-1641] 1790: 53-54).

También había sido digno de ponderación, en junio de 1658, el nubarrón de fuego "por no decir cometón" que se había levantado desde San Isidro, y que "corrió hasta Palacio, donde se paró" (Barrionuevo [19VI-1658] 1968, II: 198). Tampoco faltaron en los pronósticos los presagios relacionados con la descendencia de los reyes y con sus negocios bélicos, lo que denota el deseo de estabilidad de la institución monárquica y 
de la conservación de la base territorial de su poder: "... se dice ha de tener esta Monarquía dos felicidades: un heredero varón de los reinos, y que ha de llegar la flotan (ibid. [4-XII-1655], I: 226).

Además de contener vaticinios relacionados con los supremos representantes del poder espiritual y temporal, los pronósticos predecían sucesos aciagos con el claro fin de lanzar advertencias a los creyentes sobre los castigos divinos si no corregían sus pecados ${ }^{35}$. Acorde con estos fines, los pronósticos con tintes apocalípticos, rayanos en lo profético, recurrían a imágenes dantescas relacionadas con los astros o con las fuerzas incontenibles de la naturaleza para causar un mayor impacto; en 1620 una profecía procedente de Francia auguraba para dicho decenio sucesos tan terribles como la aparición en el cielo de lunas inyectadas en sangre y un terremoto generalizado en todo el orbe ${ }^{36}$. La Iglesia ponía a veces su granito de arena para consuelo de los afligidos y entonces aparecían personajes como un tal abad Joaquín, asegurando que "este año de 57 se han de ver cosas maravillosas y grandes y no vistos portentos en todas partes" (Barrionuevo [23-I-1657] 1968, II: 55). Dentro de la vida eclesiástica, también las mujeres hicieron gala de virtudes "proféticas" o de un protagonismo mágico, encontrándose desde una monja francisca que "hacía milagros", condenada por la Inquisición y llevada a Valladolid en medio de "señales de fuego en el cielo" ${ }^{37}$, hasta una beata que vivía en la calle de Alcalá, "tenida por santa", que había anunciado para Madrid "una grande calamidad y [sic] infortunion 38 .

En una época de crisis y catástrofes (la sequía entre ellas) no podían faltar los profetas que, como tantos otros "prodigios" iban a parar a la Corte; así, habiéndose "avisado" de Sevilla que "una niña de ocho años, hija de gente humilde y pobre, tiene espíritu de profecía (manifestado en el cumplimiento del vaticinio de una lluvia largamente esperada), los reyes habían mandado "se la traigan, que la quieren tener en Palacio" (Barrionuevo [5-I-1656] 1968, I: 235). En el episodio de esta niña profeta no estaba ausente, para reforzar su impacto, el marco de pobreza y hu-

\footnotetext{
${ }^{35}$ En una carta enviada desde Lisboa a *un caballero desta Corte [de Madrid]", con referencia a las fuertes tempestades que hubo durante el reinado de Carlos II, se decía: "Estos truenos y rayos que han caído, [i] qué es sino tocar el Cielo cajas y trompetas, publicando guerra a los mortales, que no se enmiendan[?]» (BNM, Varios Especiales -en adelante VE-, 24-8).

${ }^{36}$ BNM (Mss 9.856, fs. 25v y 26).

${ }^{37}$ BNM (Mss. 9.404, f. 99).

${ }^{38}$ Se trataba de Ana Gallo, a quien el Santo Oficio había llegado a interrogar "cuatro o seis veces" (Barrionuevo [5-VI-1658], 1968, II: 191).
} 
mildad que facilitaba la inmediata asociación de su figura con la de Jesús en el pesebre de Belén, imagen evocadora de pureza y "santidad".

Por último, la reacción ante tan notable proliferación de pronósticos y profecías llegó a adoptar formas satíricas, como la del escrito titulado Discurso astronómico y Pronóstico general desde el año de 1683 hasta la fin del mundo, firmado por el "Bachiller Carambola, heredero de las carcajadas de Demócrito" (en Sánchez Alonso 1981: 447), donde se anunciaba que:

El Invierno en la Corte será abundante de tajadillas, para sustento de lacayos; la Primavera de flores, para envidia de los fulleros: el estío de pepinos, para socorro de los Dotores y el Otoño de calabazas, para consuelo de los pretendientes (ibid.).

\section{Las relaciones de prodigios}

Dentro del tipo de documentación utilizada para este estudio, las relaciones de prodigios ${ }^{39}$ representan sin duda una valiosa fuente para el análisis de la cultura del Barroco y de sus manifestaciones extrarracionales, así como del marco contrarreformista que imponía la sujeción de la cristiandad a la suprema autoridad del Papa en contra de cualquier desviación herética. Además de los fenómenos celestes o catástrofes naturales, otro tipo de sucesos extraordinarios se prestaron a la difusión de mensajes aleccionadores, tales como la aparición de bestias sorprendentes o de animales monstruosos y el nacimiento de seres anormales ${ }^{40}$. Aparte de este fin moralizante, los hechos portentosos también podían ser utilizados como un recurso "subversivo" para canalizar las tensiones sociales y el disconformismo de amplios sectores respecto del orden vigente, manifiesto en veladas acusaciones a las instituciones temporales o espirituales ${ }^{41}$.

Los prodigios alusivos a la fecundidad y a los alumbramientos sugieren un rico campo de análisis. En primer lugar, los embarazos o los partos

\footnotetext{
${ }^{39}$ Con respecto a la significación de los hechos "prodigiosos" que aparecen en las relaciones del siglo XVII, pueden consultarse los estudios de A. Redondo, V. Infantes, A. Morel D'Arleux, y J. P. Étienvre en Las Relaciones de sucesos en España, 1500-1750 (1996), donde se analizan los diversos géneros "proveedores" de noticias como así también su trasfondo ideológico, dentro del espíritu contrarreformista nacido al amparo del Concilio de Trento en 1570.

${ }^{40}$ Otros casos de prodigios están descritos en Redondo (1996: 288).

${ }^{41}$ Véanse al respecto las observaciones de Maravall (1975: 55-127) sobre el surgimiento de comportamientos críticos y movimientos de reacción social durante el Barroco.
} 
"prodigiosos" - atento a la constante preocupación que aparece en algunos testimonios por las preñeces de las reinas, de cara al esperado nacimiento del heredero- siempre eran noticia. Así por ejemplo, se informa de la "monstruosa" preñez de una mujer, madre ya de cuatrillizos de apenas un año, "que parece trae una razonable tinaja en lugar de barriga" (Barrionuevo [13-X-1655] 1968, I: 204). Otras cartas de este mismo cronista van más lejos en la inserción de avisos cargados de alusiones a la potencia masculina y a su capacidad para engendrar, lo que podría interpretarse como un velado reproche a la ausencia de dones viriles en el rey "hechizado" o bien como la expresión de un deseo de fecundidad con respecto al mismo:

\begin{abstract}
A un músico capón del Rey, que se llama don Lázaro ${ }^{42}$ del Valle, le han retoñado los genitales, y está tan gozoso que los enseña a todos. Lo que es por curiosidad no puedo dejar de verlos, cosa de que los capones todos están muy gozosos, no perdiendo ninguno las esperanzas de verse algún día hombre hecho y derecho (ibid. [26-VI-1655], I: 154).
\end{abstract}

Por otra parte, en lo referente a seres anormales contamos con dos relaciones que ejemplifican el fenómeno a la perfección, una de ellas referida a una criatura monstruosa que ha nacido en esta Villa de Madrid" ${ }^{43}$ con características hermafroditas ${ }^{44} \mathrm{y}$ otra que anunciaba "un gran prodigio de la naturaleza que ha llegado a esta Corte en una niña giganta" 45 (figs. 1 y 2). La relación del primer caso, el raro alumbramiento de un ser con dos naturalezas, ala de niña en la parte común y la de niño en mitad de la frente" ${ }^{46}$, cuyo retrato acompaña al texto, contiene una serie de elementos que inducen a pensar no sólo en la condena del bestialismo - del que se suponía derivaban terribles consecuencias a la hora de procrear (Morel D'Arleux 1996)—, sino también en la reprobación de las relaciones homosexuales o bien de las uniones heterosexuales contra natura; de ahí que al final del relato, se expresase la intención de que "sirva de ejemplar a todos los Católicos Cristianos, por si en su generación hubo algún exceso vicioso, que suele el Cielo cas-

${ }^{42} \mathrm{El}$ nombre de Lázaro recuerda ya el bíblico "levántate y anda", a modo de invocar metafóricamente el milagro de la procreación.

${ }^{43}$ Relación verdadera y caso prodigioso y raro que ba sucedido en esta Corte el día catorce de mayo de este año de 1688..., BNM, VE 24-17.

${ }^{44}$ Véase el análisis realizado por Morel D’Arleux (1996) en torno a la relación de este suceso y de su representación gráfica.

${ }^{45}$ BNM (VE 24-16).

${ }^{46}$ BNM (VE 24-17). 


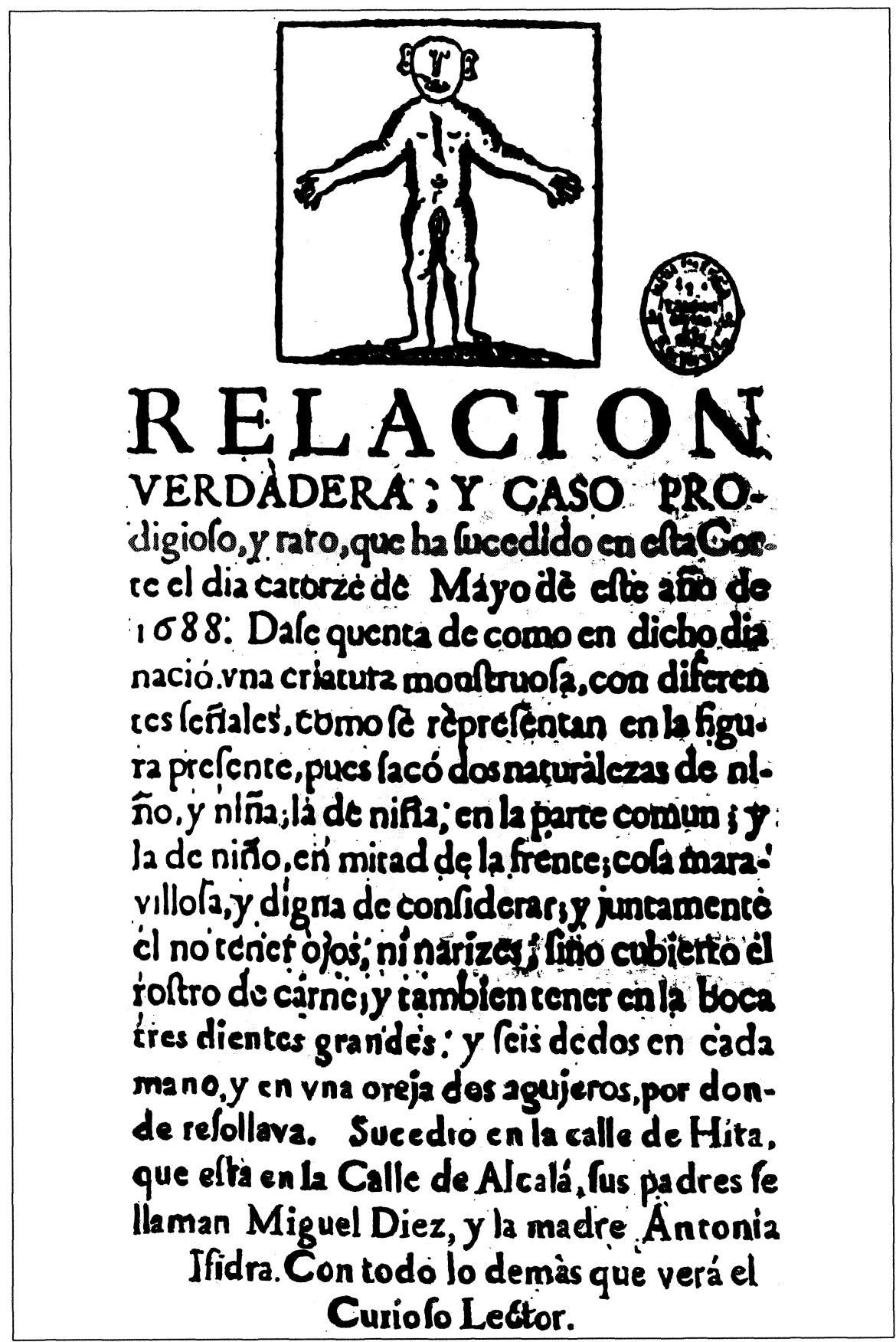

FIGURA 1.-Relación del nacimiento de una criatura monstruosa en Madrid. Biblioteca Nacional de Madrid. 


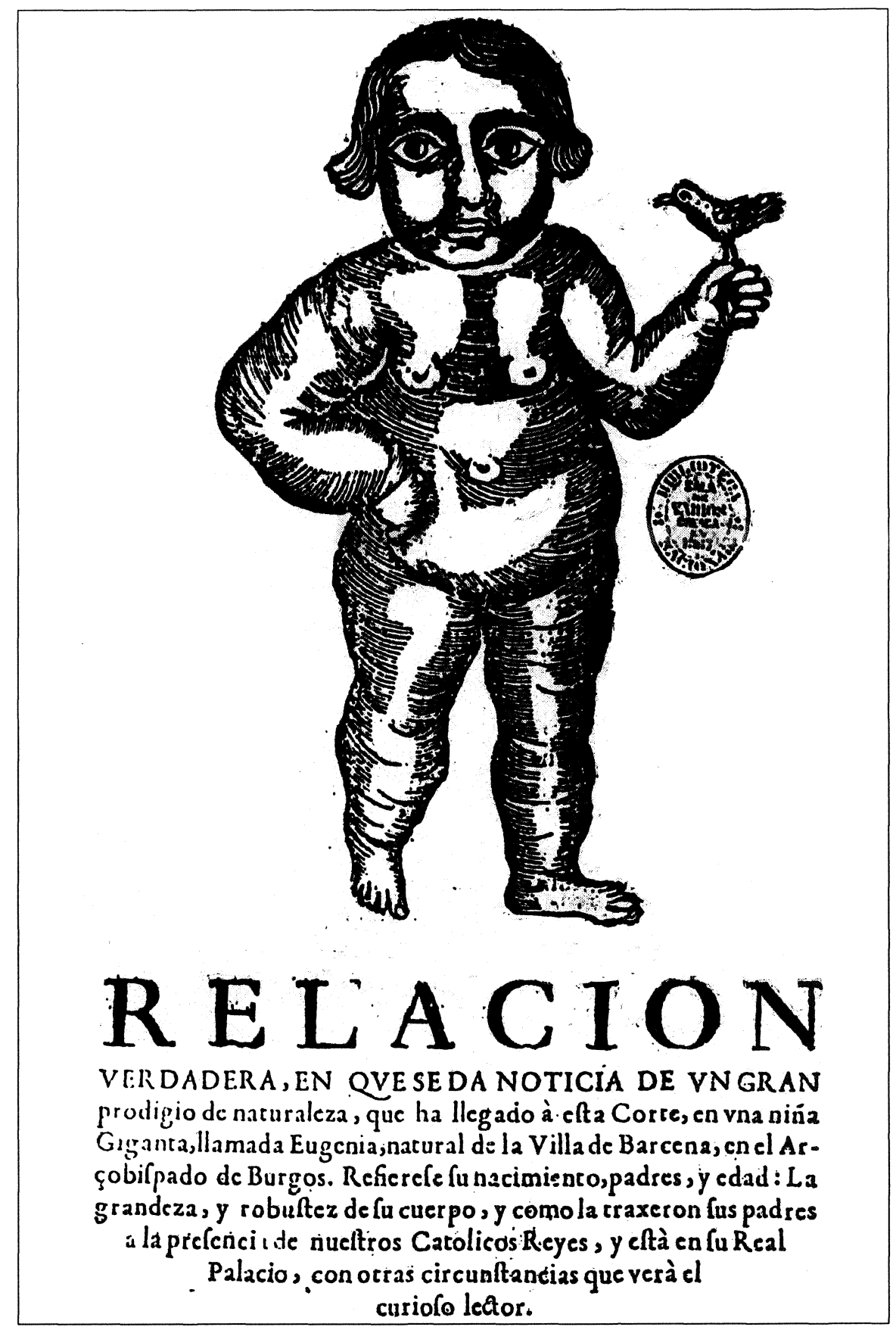

Figura 2.- Relación del nacimiento de una niña giganta en Burgos. Biblioteca Nacional de Madrid. 
tigar en los hijos travesuras" ${ }^{47}$. Hay autores que han remarcado en este suceso, la advertencia dirigida a los creyentes, en cuanto a no forzar los designios de la Providencia respecto de la procreación, aludiéndose de modo indirecto a los denodados esfuerzos del rey Carlos II por engendrar un heredero (Redondo 1996: 296-297), para lo cual, agregamos, se habría apelado a lo divino, a lo humano y claro está, a lo mágico. El carácter aleccionador de la noticia queda además ratificado mediante la incorporación de un recurso puramente barroco: el elemento visual, representado por el dibujo de los monstruos, que acompaña a las narraciones de prodigios ${ }^{48}$.

En este ser con dos naturalezas, paradigma de la monstruosidad, se reflejaba a su vez la oposición "entre lo que tiene orden y carece de él", rasgo recurrente en las diversas manifestaciones de la cultura y del pensamiento barrocos (Bouza Álvarez 1999: 223). Ello explicaría, además, la presencia en la Corte de todo un séquito de individuos deformes (los enanos, por ejemplo, pintados magistralmente por Velázquez) o con sorprendentes anomalías que se mandaban traer a palacio, como ocurrió con el caso antes mencionado de la "niña giganta", nacida durante el reinado de Carlos II ${ }^{49}$. Este afán de congregar en la residencia real todo tipo de "portentos" obedecía, por lo demás, al propósito de ratificar la majestad monárquica, reproduciendo en su ámbito cotidiano "un pequeño universo" en el que se plasmaba todo el orden de la creación (Bouza Álvarez 1996: 161).

Por último, debido a la falta de conocimientos científicos sobre la materia, ciertos nacimientos inducirían a ser tratados como "prodigios", lo que puede constatarse a través del suceso ocurrido en Madrid, reflejado en una relación de 1625: un alumbramiento del que "nacieron dos niñas pegadas, con dos cabezas, cuatro pies y cuatro brazos y un ombligo" (en Sánchez Alonso 1981: 139), rasgos éstos que corresponderían al arquetipo de las siamesas.

Con respecto a los engendros que combinaban rasgos humanos y animalescos, una verdadera conmoción había causado el descubrimiento en Cerdeña, "en lo fragoso de las montañas", de "un monstruo con pies

47 Ibid. Por lo demás, el nacimiento de seres deformes se explicaría por las frecuentes uniones entre personas con un parentesco estrecho aunque, mediante la exageración, tales anormalidades pasaban a convertirse en un excelente recurso narrativo con el fin de moralizar.

48 Véase al respecto el análisis de Maravall (1975: 498-520) sobre la utilización de recursos visuales en el Barroco, para captar la atención del público.

49 BNM (VE 24-16). Poco después, el rey Carlos II ordenaría a su pintor de cámara, Juan Carreño de Miranda, la realización del retrato de este portento (Bouza Álvarez 1996: 49). 
de cabra, brazos de hombre y rostro humano, con algunas cabezas y caras y aunque tiene en ellas diversos ojos y bocas, sólo come por una" (Barrionuevo [24-X-1654] 1968, I: 73). Este tipo de noticias, cuyo tono sensacionalista se complementaba con el retrato del monstruo en cuestión ${ }^{50}$, perseguiría también la reprobación de la zoofilia, que asume en la narración las características de una acción inducida por Satán. Las zonas montañosas ${ }^{51}$ o selváticas representaban el marco natural de ciertos sucesos raros y también de prácticas "diabólicas" y condenables como el bestialismo, reforzándose la imagen de albergue de fuerzas oscuras de dichos ámbitos mediante el recurrente uso del calificativo fragoso.

Por último, tampoco faltaron las bestias que causaban pavor como la "gran ballena, de disformidad espantosa" aparecida en Oviedo (Barrionuevo [4-X-1656] 1968, II: 2) ${ }^{52}$ o el "animal a modo de caimán, con sus conchas y garras, tan grande como un lebrel", hallado en un monasterio en medio de la putrefacción que, según Barrionuevo, "era mucha" (ibid. [30-X1655], I: 213). Recuérdese que en el imaginario popular el demonio se encuentra asociado a la figura de animales monstruosos, cuyos rasgos definitorios eran la fetidez y las formas temibles y repugnantes.

En resumen, "las monstruosidades de la naturaleza" eran instrumentos con los que Dios, en su suprema majestad, demostraba su ira por los pecados del mundo e instaba al arrepentimiento: "Sírvase la historia de la observación de los monstruos por lo que suelen anunciar", rezaba en una relación que avisaba el nacimiento de un monstruo en Huesca, en $1659^{53}$. La importancia de los prodigios residía en su calidad de portadores de malos presagios, de ahí que Barrionuevo ([4-XI-1654] 1968, I: 78), luego de narrar las pérdidas sufridas ante los franceses, le expresara a su destinatario: "Parece que todo sucede al revés. Algo de esto debe pronosticar el monstruo que ha parecidon.

Los prodigios, además de aleccionar a los laicos, cumplían también con el fin de llamar a enmienda al estamento eclesiástico y en especial a

${ }^{50}$ Barrionuevo ([28-X-1654] 1968, I: 74) expresaba a su destinatario que "el retrato del monstruo anda ya, aunque no impreson.

${ }^{51}$ En otra carta se consigna que el mismo día en que habían quemado en Alcalá "al enamorado de su burra", se recibió aviso de que "quedaba preso en las montañas otro que se echaba con una lechona" (ibid. [15-VII-1655, I: 165). El subrayado es nuestro.

${ }^{52}$ Los portentos, que en un principio tenían lugar en el extranjero, pronto aparecen en España: "La monstruosidad no se sitúa ya en un espacio lejano, exótico, sino que se interioriza en el espacio hispánico", como síntoma de la "crisis de conciencia" que vive la nación bajo el reinado de Carlos II (Redondo 1996: 295).

${ }^{53}$ BNM, Mss 2.270, f. 192. 
sus representantes femeninas; aunque tales hechos, dados el ámbito y la condición de las personas a las que estaban referidos, se presentan como milagros. Los conventos de monjas se prestaban - tanto como los de varones- a todo tipo de transgresiones, al ser receptores no sólo de mujeres con una vocación auténtica, sino también de una considerable cantidad de huérfanas, de viudas o de damas de la nobleza, que no tenían otro recurso que recluirse en ellos. Por ello no sorprende que algún aviso irrumpiese para corregir ciertos desenfrenos, como aquel que daba cuenta del "prodigio tantas veces repetido en esta pérfida Nación y tantas veces olvidado", de un Niño Jesús "azotado y corriendo sangre encontrado en la celda de un convento cuyas monjas recibían la visita de caballeros (Pellicer [1-XI-1639] 1790: 92); con ello no sólo se alertaba respecto al castigo por unas prácticas corruptas sino también de la posibilidad de una preñez escandalosa. Como contrapartida, las órdenes religiosas, según se observa en algunos avisos, sacaban a relucir su repertorio de frailes y monjas muertos en olor de santidad o con fama de "milagrosos" a fin de lavar su imagen ante la sociedad.

Los prodigios no sólo respondían a las categorías antes señaladas sino que también se manifestaban en ciertos sucesos, como el tañido de la famosa campana de Velilla, portadora de buenos y malos presagios al sonar por sí misma, aunque algunos, como Pellicer, dudasen de este "milagro" ${ }^{54}$. Tal reiterado acontecimiento venía dando de qué hablar desde hacía tiempo y así, en ocasión de la mudanza de la Corte a Valladolid, cuyos ainconvenientes y malos efectos" habían sido notorios según León Pinelo (1971: 175), "se aplicó a su anuncio haberse tocado poco antes la Campana de Velilla en Aragón, que suele ser mensajera de grandes trabajos".

Existían además otros portentos ${ }^{55}$, que podrían inscribirse dentro de la faceta "lúdica" de la vida madrileña. En este terreno, dada la importancia de las manifestaciones teatrales y otros espectáculos públicos en el Madrid de los Austrias, contamos con el significativo ejemplo de los prodigios de la tramoya, que podría calificarse como "magia escenográfica" ${ }^{56}$. En 1655 ,

\footnotetext{
${ }^{54}$ Tras anunciar que corría la voz de que ase ha tocado la campana de Velilla, que se tiene en opinión de milagrosa", la crónica se cerraba con la frase: "No sé que sea cierton (Pellicer [25-III-1642] 1790: 235).

55 Los portentos representan una forma de prodigio, siendo definidos como cosas "que parecen contra natura", de acuerdo con las distinciones lexicográficas marcadas por Redondo (1996: 288).

${ }^{56}$ En teatro, "lo que se hace es provocar efectos mágicos por un sistema puramente mecánico" (Caro Baroja 1987: 54). En el siglo XVII se asiste en España a la magia como espectáculo, alcanzando notoriedad las comedias "mágicas" con personajes del "ciclo caballeresco" y de la Antigüedad clásica (ibid.).
} 
las actuaciones de un tramoyista llamado "Bacho", probablemente de origen italiano ${ }^{57}$, hacían las delicias de la Corte ${ }^{58}$, siendo sus hazañas descritas con lujo de detalles, como una expresión del deseo de abundancia de la que muy lejos se estaba en tiempos de tantas carencias alimenticias:

[...] echa por la boca, después de haberse bebido dos cántaros de agua, diversas cosas, vinos de todas suertes y colores, aguardiente y vinagre, confites, ensalada, flores y aguas de colores y otras cien mil baratijas, de que los Reyes han gustado mucho (Barrionuevo [17-XI-1655], I: 219).

\section{Demonios y oficiantes de la magia}

En el inquietante mundo cotidiano del Madrid de los Austrias, el capítulo del demonio ocupa un lugar de privilegio en el anecdotario mágico, según se ha visto en las relaciones de prodigios. No obstante, de cara a los objetivos de este trabajo, sólo añadiremos algunas observaciones en lo concerniente a su carácter de "noticia" en las fuentes consultadas. Señalado, junto con las brujas, como una de las "obsesiones" del mundo europeo en la época que tratamos (Gómez-Centurión Jiménez 1999), el demonio representa el recurso perfecto tanto para condenar a los enemigos ${ }^{59}$ como para censurar conductas abominables ${ }^{60}$, incomprensibles $\mathrm{o}$ indicadoras de alteraciones psíquicas ${ }^{61}$.

La omnipresencia del demonio llegaba también a inspirar narraciones coloridas, adornadas con efectos especiales para alertar sobre los poderes

${ }^{57}$ En Italia, la escenografía y la tramoya experimentaron un gran desarrollo en los siglos XVI y XVII (ibid.: 50-57).

${ }^{58}$ Tanto fue así que en noviembre de 1656, "los arrendadores de las comedias" lo habían mandado a Toledo "para que [en] la Cuaresma tenga la corte algún entretenimiento" (Barrionuevo [20-XI-1656] 1968, I: 229).

59 Los embajadores franceses alojados en el Retiro hacia mediados del siglo XVII eran diabolizados por Barrionuevo, no sólo en su condición de enemigos de España sino también por su control de la información, obtenida mediante "alianzas" con el demonio: "Dícese que esta gente del Retiro se gobiernan por familiares que le dicen todo, y traen cartas de Francia siempre que las han menester, y saben todo cuanto pasa" (ibid. [27-XII-1656], II: 41).

${ }^{60}$ En este sentido, es ilustrativa la noticia de la muerte de dos mujeres jóvenes en el Prado de San Jerónimo (famoso en ese entonces como refugio de gentes con vida alicenciosa"), tras haber sostenido tratos carnales con "dos demonios íncubos" (ibid. [10-VII-1658], II: 206).

${ }^{61}$ Véase el caso, por ejemplo, del suicidio de un arquero de la guardia real, del que se decía "que estaba loco, hechizado o espiritado" (en González Palencia 1942: 45). 
del Maligno, como la relación escenificada en la cárcel de la Corte, en la que se advierte del peligro de mentar al Diablo y de ponerse a su servicio, tal como había obrado un preso en pos de su liberación, mostrándose desce un comienzo del escrito —en verso- el carácter aleccionador del "Suceso":

Atención me den, no tanto/ porque se trai [sic] el aviso/ con los créditos de cierto,/ apoyos de Peregrino./ Cuanto a que sirva de enmienda/ a los que tienen por vicio/ maldecir y dar al diablo,/ alma, hacienda, obras e hijos ${ }^{62}$.

Amén de aparecer como una "escamada serpiente" ${ }^{63}$ —según consta en esta relación - el demonio podía encarnarse o bien tener tratos con los mil y un personajes de la vida mágica de Madrid. Entre ellos estaban los hombres y las mujeres que se dedicaban a las artes adivinatorias, grupo en el cual pueden agruparse desde las gitanas que decían la buenaventura hasta los expertos en echar las habas (Villarín 1993), pasando por los frailes que confeccionaban horóscopos (Blázquez Miguel 1989: 204) y por toda una grey de falsos astrólogos, matemáticos, adivinadores y curanderos "O por mejor decir embusteros" (Liñán y Verdugo 1620: 95), contra los que se prevenía a los forasteros que acudían de visita a la Corte. Aquellos personajes - los "capigorras" (ibid.: 92v.) - simulaban ser estudiantes para mejor engañar al público, "siendo la verdad que en toda su vida abrieron libro ni estudiaron proporción de Astrología" (ibid:: 92-93).

A veces podía darse el caso de que un solo individuo reuniese en su persona varias "habilidades", tales como la de curar, la de vaticinar el porvenir o la de proporcionar "ayudas" para el logro de diversos fines, virtudes todas que concurrían en el famoso portugués Mateo Rodríguez, que era "visitado y regalado a menudo de Su Majestad" ${ }^{64}$, y muy conocido en la Corte por "las señoras principales y vulgo de ella" ${ }^{65}$. Tal clientela le había permitido a este personaje, llamado el "esterero santo", acrecentar su popularidad y también sus arcas —razón por la que abandonó su poco rentable oficio de hacer esteras-, aunque ello no le libraría de la condena inquisitorial y de la muerte en la hoguera en $1638^{66}$.

También designados como "embusteros/as", en tanto sus pociones y demás recursos mágicos sólo servían para embaucar a las gentes, los

\footnotetext{
${ }^{62}$ Relación verdadera sobre lo ocurrido en la Cárcel de Corte, a un preso natural de Madrid... BNM (VE 114-12).

${ }^{63}$ Ibid.

${ }^{64}$ BNM, Mss 18.447, f. 103.

65 Ibid., f. 116v.-117.

66 Ibid.
} 
hechiceros y hechiceras - muchas de éstas "hijodalgas" o "cristianas viejas" ${ }^{67}$ - por lo general unían a sus actividades básicas — los embrujosel envenamiento y la alcahuetería, contándose por miles sus supuestas víctimas. No había pues distingos sociales ni de sexo entre quienes se consideraban objeto de encantamientos o apelaban a las prácticas ocultas con fines diversos; en la larga lista de acusados por maleficios contra personas reales encontramos a aristócratas, frailes o a damas cortesanas. Como bien señalara Caro Baroja (1973: 113), "la hechicería sube al castillo del noble, al palacio del obispo, al alcázar del rey".

El Madrid de los Austrias casi podría llamarse la Corte de los hechizados, aun cuando se intentara mantener el silencio sobre estas cuestiones "por razones de Estado" (Barrionuevo [10-IV-1658] 1968, II: 168) y practicar los correspondientes conjuros "en secreto" (ibid. [7-10-1654], I: 65). Las intrigas palaciegas eran caldo de cultivo para la propagación de prácticas mágicas, a las que ni siquiera el mismo monarca lograba escapar, debiendo recurrir a expertos para contrarrestarlas. Las manos de la brujería estaban presentes en todo acontecimiento aciago para la monarquía y, en especial, en las enfermedades o muerte de cualquiera de sus miembros:

Muy vivo ha corrido [el rumor] estos días en esta Corte que el Inquisidor General había sacado de Palacio con licencia de S.M. una criada de las que servían a nuestro Príncipe difunto y llevádola a la Inquisición, sobre lo cual se ha discurrido largo en misterio de hechizos; pero se ha verificado que todo ha sido patraña (Barrionuevo [11-II-1662] 1968, II: 270).

Hacia agosto de 1620 se había extendido la noticia de que los dos hechiceros llegados de Flandes con abundante literatura referida a la magia - en total los libros que formaban parte de su equipaje pesaban 72 libras-, habían sido traídos por disposición del mismo Felipe III, con lo cual muchos use han alargado a decir [informaba el aviso anónimo] vienen a deshechizar al Rey" ${ }^{68}$.

Tres años más tarde aparecen nuevas condenas por intentar embrujar al Rey y envenenar al conde de Olivares, castigándose por tales delitos y con diversas penas a un miembro de la guardia de arqueros, a un fraile y a una mujer "que había de hacer los hechizos" (González Palencia 1942: 69). Éstos persiguieron al rey Felipe IV casi hasta el final de su reinado;

${ }^{67}$ Cartas de Andrés de Almansa y Mendoza... ([22-VII-1621] 1886: 42). Pellicer ([1XI-1639] 1790: 92), a su vez, informa de la mejoría del marqués de las Navas y de la detención de "ciertas damas hechiceras y entre ellas alguna de porte, que acaso le ocasionaban el irse muriendo".

${ }^{68}$ BNM, Mss 18.723 (7), fs. 100-100v. 
en la Pascua de 1658, un aviso consignaba que, gracias al "tiempo Santo", se había descubierto "un hechizo puesto al Rey en un espejo donde siempre al pasar se miraba. Dícese le entregaron al fuego, y que se calla por razones de Estado" (Barrionuevo [10-IV-1658] 1968, II: 168). En 1661, un verdadero alboroto se produjo a raíz del descubrimiento de unas láminas con los nombres de Felipe IV y Luis de Haro y sendos corazones flechados, luciendo unas inscripciones misteriosas que se mandaron descifrar, aunque «o peor es que sobre esto se va añadiendo más y más de mano en mano" (ibid. [carta sin fecha], II: 157), apreciaciones que denotan una advertencia, por parte del señalado cronista, acerca de lo que estudios actuales han definido como "creación" del acontecimiento.

Las aventuras mágicas eran de prever en el mundo palaciego, en tanto albergue de validos y nobles descontentos que aspiraban a mayores cotas de poder. Entre los casos más sonados se encuentra el de Rodrigo Calderón, marqués de Siete Iglesias, de cuya ejecución en 1621 se habló en todos los anales, noticias y avisos de la época. Acusado de whaber dado hechizos y con ellos procurado atraer las voluntades del Rey Nuestro Señor y de otras personas" (en González Palencia 1942: 4), el citado marqués pasaría a la leyenda, además, por la "valentía" y el orgullo con que afrontó su muerte.

El hecho de que las noticias sobre hechizos acabaran colándose indica que no había intención de ocultarlas y sí de dar una especie de escarmiento, aunque las conjuras se practicasen en "secreto", tal como había ocurrido con el controvertido marqués de Liche, durante el reinado de Felipe IV (Barrionuevo [7-X-1654] 1968, I: 65). El relato del descubrimiento de las brujerías de que fue víctima este personaje no tiene desperdicio:

El marqués de Liche ha tornado a recaer, unos dicen de debilidad y flaqueza de estómago, y lo más cierto de hechizos. Anoche prendieron tres damazas, ricas y de buena cara, por hechiceras [...] Estaba un gran señor en visita con la una, que duró hasta las once. Esperaron que se fuese por excusar alborotos, y luego la prendieron. De esta mercancía hay en Madrid gran cantidad (ibid. [21-X-1654], I: 71). El subrayado es nuestro.

Años más tarde, el citado marqués aparece del lado de sus antiguos victimarios, aunque su delito habría de adjudicarse a las travesuras demoníacas. Acusado de intentar "volar con pólvora el coliseo del Buen Retiro" (ibid. [:1662?], I: 272) y de querer envenenar a unos presos que estaban en la cárcel de la Corte, Liche fue detenido y enviado a Segovia, corriendo muy pronto el rumor de que estaba endemoniado. En las reyertas cortesanas el demonio y las brujerías venían muy a cuento: "la 
materia de los hechizos", como bien expresaba Barrionuevo, "han tomado tanto cuerpo" que lo justificaban todo, pues al marqués de Liche

ahora le excusan todas sus acciones y en especial esta enorme del incendio, con decir que está endemoniado y todos los médicos de esta parte darán firmado que lo está, por ser sobrenatural, en opinión de ellos la enfermedad que padece ( $i b i d$. [imarzo de 1662?], II: 274).

Por debajo de la aristocracia encontramos una gruesa legión de mujeres hechiceras, recibiendo diversas penas por sus delitos ${ }^{69}$. Aunque la hoguera era el castigo aconsejado por célebres juristas en la Edad Media (Caro Baroja 1973: 113), rara vez aparece en las fuentes consultadas, en contraposición a otras penas como la de la galera, la coroza y los azotes o el destierro.

La parafernalia que acompañaba a quienes ejercían las artes maléficas podía consistir - tal el caso del material incautado a unas hechicerasen "manos de niños muertos, cabellos, dientes, cintas de atacar de hombres y otras mil cosas" (Barrionuevo [21-X-1654] 1968, I: 71) u objetos tan curiosos como

un libro de pliego entero, hecho de retratos, con su abecedario, número, calle y casa de las mujeres que querían ser gozadas, donde iban los señores y los que no lo eran también, a escoger [...] donde se dice había gente de muy buen porte de todos estados, y zurcidoras de honras tan bien como de paños desgarrados (ibid. [29-V-1656], I: 281).

Finalmente, la vida cotidiana de Madrid en la época de los Austrias estaba impregnada de supersticiones y de multitud de gestos con los que se pretendía conjurar la mala suerte. Dentro de los "portentos y casi milagros" y de los mil sucesos que componían a diario la crónica mágica de la ciudad, las almas en pena ocupaban un lugar privilegiado. Entre las que sin descanso desasosegaban el sueño de la vecindad, se hallaba la de Antonio de Amada, condenado injustamente bajo la acusación de haber asesinado a su amo, el marqués de Cañete; a raíz de este suceso, se decía que el fantasma de la inocente víctima rondaba la casa de la viuda del marqués "por los asombros que de noche se ven en ella y ruido de cadenas y aullidos" (Barrionuevo [12-IX-1654] 1968, I: 59). Estas noticias, que a primera vista nos sugieren un cuento de "aparecidos", contiene sin embargo elementos que insinúan los conflictos sociales de la épo-

${ }^{69}$ En el caso de la "famosa alcahueta Margaritona" de 88 años, se la envió a galera perpetua con coroza aunque "no la azotaron, porque se tuvo por cierto moriría si lo hacían" (Barrionuevo [29-V-1656] 1968, I: 281). 
ca y la demonización de una aristocracia pretenciosa y detentadora de privilegios (encarnada en la figura del marqués), como así también el trato desigual brindado a los más desvalidos, sobre quienes recaía todo el peso de la ley. En relación a este episodio, Barrionuevo comentaba que si a él se le hubiera "aparecido" el alma de Antonio de Amada, tal como le había ocurrido a un jesuita,

no le dejara de preguntar por el alma de su amo [el marqués de Cañete], aunque me respondiera que por guardada, no la había visto; que los demonios, cuando va allá algún señor, le encierran con gran cuidado, temerosos no se quieran levantar con el infierno, como lo hacen acá en el mundo (ibid. [29-VIII-1654], I: 53).

Por último, entre las múltiples supersticiones que se ponían de manifiesto en el día a día, encontramos desde la mariposa de mal agüero que posada en la mano de un hombre le anuncia la muerte ${ }^{70}$, hasta episodios raros y plagados de presagios, como el de la criatura que tras una catástrofe se mantenía con vida entre los brazos de su madre muerta (en González Palencia 1942: 78-79) o el del caballo que subió a un tejado en la calle de las Postas en Madrid, "como queriendo, a mi parecer, ser otro Pegaso para huir de un mundo tan malo", suceso del que, según decía Barrionuevo, pronto iban a conjeturarse "mil agüeros" (Barrionuevo [7-VII1655] 1968, I: 162).

La magia barroca presentaba también su faceta "coleccionista", materializada en la conservación de las más variadas reliquias e incluso de objetos relacionados con personajes cuya muerte había quedado impresa en las páginas de sucesos raros (como la del marqués de Siete Iglesias ${ }^{71}$ ), de figuras de monstruos ${ }^{72}$ o de piedras curativas, entre otros (Bouza Álvarez 1999: 246-247). También existía un auténtico culto fetichista en torno a las prendas de religiosos considerados "santos", como la pretina de San Juan de Ortega, de la orden de los jerónimos, que "dicen obra milagros en orden a concebir las mujeres", razón por la que fue llevada a palacio: “Pidióla el Rey [comenta Barrionuevo], y el que la trujo murió en llegando acán (Barrionuevo [2-II-1656] 1968, I: 244).

${ }^{70}$ BNM (Mss 9.856, f. 6v-7.).

${ }^{71}$ El cuchillo con que habían ajusticiado a este aristócrata, junto a otras cosas de su pertenencia, se hallaba en manos de un coleccionista de Madrid (Bouza Álvarez 1999: 246).

72 En las colecciones podían hallarse cosas tan fabulosas como un basilisco aacecinado" (ibid.: 247). 


\section{CONCLUSIÓN}

Las diversas manifestaciones "mágicas" que saturan la vida cotidiana de Madrid en el siglo XvII constituyen uno de los rasgos característicos de la cultura del Barroco. Detrás de ese pensamiento mágico aparecen los conflictos y tensiones de una sociedad sacudida por todo tipo de flagelos "reales" (guerras, crisis económicas, pestes, caída demográfica) y atormentada a la vez por los negros presagios que marcan los pronósticos astrológicos, las profecías y los prodigios de todo tipo que se suceden día a día en la Villa y Corte así como en otras provincias de España y en el resto de las naciones europeas. Las supremas instituciones de la época - monarquía e Iglesia - "estimulan" esta atmósfera mágica y prodigiosa, con el fin de mantener el statu-quo y la obediencia social. Los monarcas, dueños de un poder absoluto y de carácter divino, despliegan una serie de medios para reafirmarlo, haciendo de palacio (por donde desfilan todo tipo de prodigios y se difunden una buena parte de las noticias mágicas) y de la ciudad misma el escenario de su magnificencia. La Iglesia, conforme a los ideales contrarreformistas, ejerce el control de los fieles mediante el rigor de sus instituciones represivas y el lanzamiento de terribles mensajes que anuncian castigos e inducen a la enmienda. Contra este control opresivo de la autoridad espiritual y temporal, la magia, ejercida desde los sectores populares, puede haber obrado como un recurso corrector de un orden social injusto y como remedio a las desgracias y calamidades de todo tipo que desde el poder se atribuían a la ira divina o a las maldades del Maligno.

\section{FUENTES Y BIBLIOGRAFÍA CITADAS}

Impresos y manuscritos (siglos XVI y XVI)

Avisos de don Jerónimo de Barrionuevo [1654-1662]. 1968. Introducción y estudio preliminar por A. Paz y Meliá. Madrid: Ediciones Atlas. Tomos I y II.

Avisos de Madrid (1620) (Anónimo). BNM, Mss 18.723 (7).

Bravo, Francisco. Avisos de Madrid. BNM, Mss. 18.666 (67) y (68).

Cartas de Andrés de Almansa y Mendoza. Novedades de esta Corte y Avisos recibidos de otras partes [1621-1626]. 1886. Madrid: Imprenta de Miguel Ginesta.

Diferentes sucesos y noticias desde el año de 1629 hasta el año de 1636 (Anónimo). BNM (Mss. 9.404).

FERNÁNDEZ ZAMBRANO, MARTín. Noticias de casos particulares sucedidos desde el año de 1621 hasta el de 1651.... BNM, Mss 2.270.

Gaceta de Madrid. ¿1665? BNM, Mss. 2.392. 
HinojosA, Julio A. DE LA. Carta enviada de la ciudad de Lisboa a un Caballero de esta Corte en 28 de septiembre deste año de 1680, por... BNM, VE 24-8.

LEÓn Pinelo, ANTONio DE. Anales de Madrid (desde el año 447 al de 1658). 1971. Transcripción, notas y ordenación cronológica de Pedro Fernández Martín. Madrid: Biblioteca de Estudios Madrileños, XI. Instituto de Estudios Madrileños.

LEÓn Soto, ANTONIO DE. Noticias de Madrid desde 1588 basta 1674. BNM, Mss. 2.395.

LIÑÁN Y VERDUGO, ANTONIO DE. 1620. Guia y Avisos de Forasteros. Madrid: Impr. Vda. de Alonso Martín. BNM, R. 10.263.

Noticias de Madrid [1621-1627]. 1942. Edición de A. González Palencia. Madrid: Ayuntamiento de Madrid.

Noticias de Madrid, desde el año de 1636 basta el de 1638 y desde el año de 1680 basta el siglo presente. Recogidas por D. José A. de Armona, Corregidor de Madrid. BNM, Mss. 18.447.

Pellicer, José. "Avisos históricos [1639-1644]". 1790. Edición de Antonio Valladares de Sotomayor. Semanario Erudito XXXI y XXXII.

Relación de nuevas de la Corte que está en la Villa de Madrid (Anónimo). BNM, Mss. 2.395.

Relación verdadera sobre lo ocurrido en la Cárcel de la Corte a un preso natural de Madrid... (Anónimo). BNM, VE 114-12.

Relación verdadera y caso prodigioso y raro que ba sucedido en esta Corte el día catorce de Mayo de este año de 1688... (Anónimo). BNM, VE 24-17.

Relación verdadera [...] sobre una niña giganta (Anónimo). BNM, VE 24-16.

SORIA, MIGUEL DE. Libro de las cosas memorables que ban sucedido desde el año de mil y quinientos $y$ noventa $y$ nueve, escritas por... BNM, Mss. 9.856 .

\section{Bibliografia}

Albert, Pierre, José SÁnchez Aranda y JuAn M. GuASCH. 1990. Historia de la prensa. Madrid: Ediciones Rialp.

BlázQueZ Miguel, JUAN DE. 1989. Eros y Tánatos. Brujería, bechicería y superstición en España. Toledo: Gráficas Campoamor.

Bouza Álvarez, Fernando J. 1996. Locos, enanos y bombres de placer en la Corte de los Austrias. Madrid: Ediciones Temas de Hoy. Bolsitemas 73.

- 1999. "La cosmovisión del Siglo de Oro. Ideas y supersticiones" y "Coleccionistas y lectores. La Enciclopedia de las paradojas", en José N. Alcalá-Zamora (dir.), La vida cotidiana en la España de Velázquez: 217-234 y 235-253. Madrid: Temas de Hoy. Colección Historia.

CARO BAROja, Julio. 1973. Las brujas y su mundo. Madrid: Alianza Editorial.

- 1987. Magia y Brujería. Estudios Vascos XVII. San Sebastián: Editorial Txertoa.

CONe, Cynthia A. y PERTti J. Pelto. 1979. Guía para el estudio de la Antropologia Cultural. México: FCE.

Chueca Goitia, Fernando. 1991. “Velázquez y el arte de su tiempo, El Madrid que vio Velázquez". Separata de las V Jornadas de Arte. Madrid: CSIC.

Díez Borque, José M. 1977. Estructura social del Madrid de Lope de Vega. Madrid: Ayuntamiento de Madrid e Instituto de Estudios Madrileños.

Étienvre, JeAn P. 1996. "Entre Relación y Carta: los Avisos", en Las Relaciones de Sucesos en España (1500-1750): 111-121. París-Alcalá de Henares: Publications de la Sorbonne. Servicio de Publicaciones de la Universidad de Alcalá. 
FRAZER, J. G. 1944. La rama dorada; magia y religión. México: FCE.

GÓMEZ-CENTURIÓN JiMÉNEZ, CARLOS. 1999. "La Iglesia y la religiosidad", en José N. AlcaláZamora (dir.), La vida cotidiana en la España de Velázquez: 255-278. Madrid: Ediciones Temas de hoy. Colección Historia.

INFANTES, VíctOR. 1996. "¿Qué es una relación? (Divagaciones varias sobre una sola divagación)", en Las Relaciones de Sucesos en España, 1500-1750: 203-216. ParísAlcalá de Henares: Publications de la Sorbonne y Servicio de Publicaciones de la Universidad de Alcalá.

Juliá, Santos, David Ringrose y Cristina Segura. 1995. Madrid. Historia de una capital. Madrid: Alianza Editorial y Fundación Caja Madrid.

La vida cotidiana en la España de Velázquez. 1999. José N. Alcalá-Zamora (dir.). Madrid: Ediciones Temas de Hoy. Colección Historia.

Las Relaciones de Sucesos en España (1500-1750). 1996. Actas del Primer Coloquio Internacional (Alcalá de Henares, 8-10 de junio de 1995. París-Alcalá de Henares: Publications de la Sorbonne. Servicio de Publicaciones de la Universidad de Alcalá.

Malinowski, BRANISLAw. 1974. Magia, Ciencia y Religión. Barcelona: Ariel.

MARAVAll, José A. 1990. La cultura del Barroco. Análisis de una estructura bistórica. Barcelona: Ariel.

Morel D'ArleuX, ANTONia. 1996. "Las Relaciones de Hermafroditas: dos ejemplos diferentes de una misma manipulación ideológican, en Las Relaciones de Sucesos en España...: 261-271.

Oliver ASÍN, JAIME. 1959. Historia del nombre Madrid. Madrid: CSIC.

REDONDO, AGUstín. 1996. "Los prodigios en las Relaciones de Sucesos de los siglos XVI y XVIIn, en Las Relaciones de Sucesos en España...: 287-297.

SÁNCheZ Alonso, María CRISTINa. 1981. Impresos de los siglos XVI y XVII de temática madrileña. Madrid: CSIC.

VILAR, PIERRE. 1981. Historia de España. Barcelona: Grijalbo.

VIllaRín, JuAN. 1993. La bechiceria en Madrid. Brujas, maleficios, encantamientos y sugestiones de la Villa y Corte, Madrid: Editorial Avapiés. 